University of Vermont

UVM ScholarWorks

\title{
Autumn Storms Trigger Enhanced Export of Iron, Phosphorus, and Carbon from a Forested Vermont Catchment
}

Austin E. Wilkes

Follow this and additional works at: https://scholarworks.uvm.edu/hcoltheses

\section{Recommended Citation}

Wilkes, Austin E., "Autumn Storms Trigger Enhanced Export of Iron, Phosphorus, and Carbon from a Forested Vermont Catchment" (2017). UVM Honors College Senior Theses. 211.

https://scholarworks.uvm.edu/hcoltheses/211

This Honors College Thesis is brought to you for free and open access by the Undergraduate Theses at UVM ScholarWorks. It has been accepted for inclusion in UVM Honors College Senior Theses by an authorized administrator of UVM ScholarWorks. For more information, please contact scholarworks@uvm.edu. 


\title{
Autumn Storms Trigger Enhanced Export of Iron, Phosphorus, and Carbon from a Forested Vermont Catchment
}

\author{
Austin Wilkes \\ Professor Andrew Schroth \\ University of Vermont \\ Geology Department
}

April 24, 2017 


\section{INTRODUCTION}

$\mathrm{Fe}, \mathrm{P}$, and DOC are chemical constituents that play critical roles in regulating water quality due to the control they exert on pollutant mobility and biological productivity. In aquatic systems Fe can act as both a micronutrient (Sorichetti et al. 2014) and a carrier for pollutants like phosphorus and arsenic (Baken et al. 2015a). The form that $\mathrm{Fe}$ is found in ultimately determines its behavior in terrestrial and aquatic systems. In riverine environments, Fe is predominantly found in two main forms: inorganic colloids (Fe oxyhydroxides) and 'truly dissolved' nano-organic colloids (Rabajczyk et al. 2014; Stolpe et al. 2013). Inorganic Fe oxyhydroxides, hereinafter referred to as colloidal Fe, have been implicated as a transport vector for $P$ due to their high surface area and charge (Baken et al. 2015b; Stolpe et al. 2013). Truly dissolved Fe, has been shown to covary with DOC due to the tendency of DOC to form complexes with dissolved Fe (Stolpe et al. 2013).

Since they often constitute the majority of Fe, DOC and P export from temperate watersheds, the biogeochemical nature of storm events is particularly important to understand. Previous studies in forested watersheds in Vermont have demonstrated that DOC concentrations may increase up to nine fold above baseflow levels during storm events due to the flushing of surficial flowpaths (Sebestyen et al. 2009). While it is well-documented that high flow events serve as a "hot moment" for DOC export (Inamdar et al. 2011; Raymond et al. 2010; Vidon et al. 2010), the impact of these events on Fe export has been relatively understudied. Rosenberg \& Schroth (2017) demonstrated that a particularly reactive fraction of Fe and $\mathrm{P}$ are exported from the study catchment during summer storms, however, this relationship has yet to be examined for storms occurring after autumn leaf fall.

As recent studies have suggested that the autumnal window is changing due to climate change (Creed et al. 2015; Capell et al. 2012), there is increasing motivation to understand the role of this period as a hot moment for biogeochemical cycling. It has been suggested that high discharge storms are occurring more frequently during late autumn due to an intensification of the hydrological cycle (Creed et al. 2015). These storms can be expected to contribute a large pulse of DOC into receiving waters of forested catchments due to the amount of labile organic matter available as leaf litter following autumn leaf fall (Meyer et al. 1998). These pulses of DOC may exacerbate "browning" of water (darkening of water leading to diminished biodiversity, fish production and water quality) (Weyhenmeyer et al. 2014; Williamson et al. 2015), and may contribute to algal blooms in receiving waters by providing an influx of dissolved Fe bound to labile DOC, which can be easily scavenged by cyanobacteria (Molot et al. 2014; Sorichetti et al. 2014).

While these high flow events have a disproportionate impact on annual loading and may contribute a biogeochemically distinct nutrient load due to the activation of new flowpaths (Sebestyen et al. 2008), they are notoriously difficult to capture due to their episodic and unpredictable hydrologic nature. Recent deployment of an insitu optical sensor network (North East Water Resource Network, NEWRnet) in streams in northern Vermont affords the opportunity to measure changes in water 
chemistry at the timescale in which these changes occur during events (e.g. 15 minute intervals). Collecting measurements with high temporal resolution enables the observation of rapid changes in water chemistry that have been historically challenging to capture, especially during storms (Birgand et al. 2010). This particular sensor technology, the s:: can spectrolyser ${ }^{\mathrm{TM}}$, measures nitrate and DOC concentrations from UV-Vis light absorbance spectra. Recent studies have demonstrated the capability of this technology to measure other light-absorbing and non-absorbing elements by establishing statistically significant correlations between their concentrations and the obtained absorbance spectra (Birgand et al. 2016; Etheridge et al. 2014). Statistical dimension reduction techniques such as partial least squares regression (PLSR) allow large sets of absorbance data across hundreds of sequential wavelengths to be reduced to a few explanatory components, which can be used to project concentrations of many different parameters of interest in catchments.

In this study, we examine the export of $\mathrm{Fe}, \mathrm{P}, \mathrm{DOC}, \mathrm{Al}$, manganese (Mn), and silica (Si) from a forested catchment in Vermont to determine the extent to which seasonality, storm timing and magnitude, and antecedent conditions influence stream loading during storms. In particular, we focus on the post leaf fall period in autumn and the storms that follow in an attempt to characterize this hot transport moment in comparison to spring and summer storms. We utilize high frequency data obtained from spectrophotometric sensors to quantify seasonal trends and project concentrations of the parameters mentioned above. Our objective is to gain insight into the impact that forested watersheds, which constitute $70 \%$ of the Lake Champlain basin (US EPA, 2015), have on the delivery of reactive Fe and P to Lake Champlain, a water body historically plagued by eutrophication issues.

\section{METHODS}

\section{Study area and field sampling}

The study was conducted at Wade Brook, a tributary of the Missisquoi River in Northern Vermont, which drains into Lake Champlain at Missisquoi Bay (Fig. 1). This site was selected both to represent forested watersheds in the Lake Champlain basin, as it is $>95 \%$ forested, and to utilize in situ spectrophotometric sensors that have already been installed as part of the NEWRnet sensor network. The installed sensors include an s::can spectrolyser, an EXO water quality sensor, and a HOBO water level logger. The s::can sensor measured UV-Vis absorbance from 220-750 nm in $2.5 \mathrm{~nm}$ increments while the EXO sensor measured $\mathrm{pH}$, conductivity, temperature, turbidity, and dissolved oxygen. Discharge was calculated using a rating curve to relate pressure and stage data as measured by the HOBO sensor. DOC concentrations were calculated by the s::can sensor using built-in algorithms that were locally calibrated using laboratory analyses. The s::can and EXO sensors were configured to take simultaneous measurements every 15 minutes throughout the duration of the study (April - November).

Baseflow sampling occurred weekly to bi-weekly from June through November with extra samples taken during or immediately after storms to capture high flow events. 
All samples were collected immediately downstream of the sensors, in concurrence with sensor measurements, to allow for high temporal resolution comparisons amongst chemical constituents of interest, as well as to verify the DOC estimations obtained from the s::can absorbance data. Samples analyzed for DOC were collected in $50 \mathrm{~mL}$ syringes before being passed through clean $0.45 \mu \mathrm{m}$ PES filters. These samples were then stored at $4^{\circ} \mathrm{C}$ until analysis. Trace metal samples were collected in $250 \mathrm{~mL}$ acid washed bottles (Optima Trace Metal grade $\mathrm{HCl}$ ) before being filtered into a $<0.02 \mu \mathrm{m}$ 'truly dissolved' fraction and a 'colloidal' fraction that was $<0.45$ $\mu \mathrm{m}$ but $>0.02 \mu \mathrm{m}$ following the Shiller (2003) method. These filtered metals samples were stored in new acid cleaned $15 \mathrm{~mL}$ bottles until analysis. This filtering process was carried out within 4 hours of sample collection.

\section{Sample preparation and analysis}

All filtered trace metal samples were acidified to $1 \% \mathrm{HNO}_{3}$ using Optima ultra-pure concentrated nitric acid. These samples were analyzed for $\mathrm{Fe}, \mathrm{Mn}, \mathrm{Al}, \mathrm{Si}$, and $\mathrm{P}$ by inductively-coupled-plasma-mass-spectrometry (ICP-MS; Element 2, Thermo Scientific) at Woods Hole Oceanographic Institution's plasma facility. A spike of scandium and indium was added to each filtered, acidified sample to calculate trace metal concentrations. Data quality assurance and control were addressed by measuring Canadian Reference Material SLRS-4 once for every 10 uncharacterized samples and by consistently measuring duplicate samples and full process blanks. All SLRS-4 measurements were within 10\% of the mean value for each measured element and all duplicate samples had less than $5 \%$ deviation from the mean value for each measured element. DOC was measured using combustion catalytic oxidation with a Shimadzu TOC-L Analyzer in order to calibrate and verify DOC estimations provided by the s::can sensor.

\section{Statistics}

All statistical analyses were carried out using R statistical software (R Core Team, 2015). Correlations were assessed using the function $\operatorname{Im}(\alpha<0.05)$. Partial least squares regressions (PLSR) were carried out using the function $p l s r$ from the PLS package (Mevik et al. 2011). This technique was utilized in order to predict analyte concentrations using UV-Vis absorbance data. PLSR is a dimension reduction technique, which reduces absorbance spectra measurements at hundreds of wavelengths to a smaller number of components that are highly correlated to analyte concentrations. It is well suited for situations with many highly correlated explanatory variables, as is expected for absorbance values from sequential wavelengths. The number of PLSR components for each analyte calibration was selected by choosing the lowest number of components that produced a nearminimum root mean square error of predicted concentration value (RMSEP) following the method in Birgand et al. (2016). PLSR was conducted using the raw spectra as well as turbidity compensated spectra. 


\section{RESULTS}

\section{Dissolved and colloidal species}

The mean truly dissolved Fe concentrations were $2.4,2.8$, and $12.8 \mu \mathrm{g} / \mathrm{L}$ and mean colloidal Fe concentrations were 4.8, 7.7, and $30.0 \mu \mathrm{g} / \mathrm{L}$ for baseflow, summer storms, and autumn storms, respectively (Table 1). Throughout the course of the study Fe was found predominantly in the colloidal phase (70\%) with a smaller fraction in the truly dissolved phase (30\%). Manganese concentrations were evenly split between the truly dissolved and colloidal phases and, unlike Fe, did not increase significantly during autumn storms. Mean truly dissolved Mn concentrations were $2.8,3.4$, and $2.2 \mu \mathrm{g} / \mathrm{L}$ while mean colloidal Mn concentrations were $2.1,2.8$, and $3.8 \mu \mathrm{g} / \mathrm{L}$ for baseflow, summer storms, and autumn storms respectively. Aluminum was measured only in a total dissolved fraction $(<0.45 \mu \mathrm{m})$ as the $0.02 \mu \mathrm{m}$ Anotop filters are made from alumina and therefore leach aluminum. Dissolved Al concentrations were 10.9, 11.8, and $51.2 \mu \mathrm{g} / \mathrm{L}$ for baseflow, summer storms, and autumn storms respectively. Dissolved and colloidal Fe and dissolved $\mathrm{Al}$ concentrations varied with discharge while Mn concentrations did not.

Dissolved Si concentrations were inversely related to discharge, with mean concentrations of 2.37, 2.39, and $1.76 \mathrm{mg} / \mathrm{L}$ for baseflow, summer storms, and autumn storms, respectively. Dissolved P concentrations showed little variation over time and did not increase greatly during storm events. Like Al, dissolved P was measured only in a total dissolved fraction $(<0.45 \mu \mathrm{m})$ as the $0.02 \mu \mathrm{m}$ Anotop filters leach P, consistent with observations from Shiller (2003). Mean dissolved $P$ concentrations were $1.2,1.3$, and $1.5 \mu \mathrm{g} / \mathrm{L}$ for baseflow, summer storms, and autumn storms, respectively. There were no statistically significant relationships between dissolved P and dissolved or colloidal metals during baseflow. During fall storms, however, there were statistically significant positive correlations between both dissolved and colloidal phases of Fe and Mn, and dissolved P (Table 2). Dissolved Al was positively correlated with dissolved and colloidal $\mathrm{Fe}\left(\mathrm{R}^{2}=0.86\right.$ and 0.70 respectively).

\section{In-situ sensor data}

Spring and fall storms delivered a relatively large fraction of DOC in a relatively short period of time. Spring storms and snowmelt delivered $25 \%$ of total study (April - November) DOC in the two weeks from April 1 - 14, and autumn storms delivered $23 \%$ of total study DOC in the 2 weeks from October 22 - November 5 (Fig. 4). Those storm events that occurred post leaf fall (Oct. 10) displayed disproportionate export of DOC in comparison to storms that occurred during the spring and summer months. Post leaf fall storms had a mean DOC concentration of $5.20 \mathrm{mg} / \mathrm{L}$ compared to $2.35,3.19$, and $4.48 \mathrm{mg} / \mathrm{L}$ for baseflow, spring storms, and summer storms, respectively (Table 1). In terms of total study water budget, postleaf fall storms accounted for $15 \%$ of total discharge and $23 \%$ of total DOC export. In comparison, spring storms and snowmelt made up 32\% of total discharge and $32 \%$ of total DOC export and summer storms made up 9\% of total discharge and $12 \%$ of total DOC export. There were strong positive correlations between DOC and dissolved Fe $\left(R^{2}=0.950, r=0.975\right)$, colloidal Fe $\left(R^{2}=0.833, r=0.913\right)$, and 
dissolved $\mathrm{Al}\left(\mathrm{R}^{2}=0.904, \mathrm{r}=0.951\right)$ (Fig. 3$)$ throughout the duration of the study. $\mathrm{A}$ negative correlation was observed between DOC and dissolved Si $\left(R^{2}=0.767, r=-\right.$ $0.876)$.

\section{Covariability between analyte concentrations and "color matrix" of water}

Significant correlations were established between absorbance spectra and dissolved and colloidal Fe, dissolved $\mathrm{Al}$, and dissolved Si (Table 3). These results must be taken with caution, as the number of samples used for PLSR calibration is small ( $\mathrm{n}=$ 22 ), and the range in analyte concentrations used for each calibration is also relatively small. Additionally, the uncertainty associated with each predicted concentration value is higher than what is typically considered acceptable for laboratory analyses. Despite these limitations, PLSR appears to be a very powerful technique for relating absorbance spectra to analyte concentrations. The coefficient of determination $\left(\mathrm{R}^{2}\right)$ was used to determine goodness of fit for each regression by comparing lab-measured values to those predicted by the model. Validation plots depicting this relationship as well as the concentration range over which each parameter was calibrated can be found in Fig. 5. Residual Standard Error (RSE) of each regression was calculated to determine the uncertainty associated with the predictions of each model.

\section{DISCUSSION}

\section{Source of dissolved species}

Throughout the study, dissolved Si concentrations varied inversely with discharge $\left(R^{2}=0.737, r=-0.859\right)$, remaining relatively constant under baseflow conditions while becoming diluted during periods of high flow. This trend is consistent with previous studies (Kerr et al. 2008) and indicates that the majority of dissolved Si is groundwater-derived and likely associated with silicate weathering in local soils and shallow aquifers. This relationship proved to be useful in describing likely sources of other elements of interest. The strong covariance between concentrations of Al, Fe, and DOC throughout the study (Fig. 3) is evidence that these chemical constituents follow similar geological flowpaths. Dissolved Al, dissolved and colloidal Fe, and DOC all exhibit statistically significant $(\alpha<0.05)$ negative correlations with $\mathrm{Si}$ and positive correlations with discharge, indicating that they are enriched in surface runoff and streambank erosion more so than groundwater. Increased export of colloidal Fe during storms is consistent with previous work, which suggests that $\mathrm{Fe}$ oxyhydroxides form at riparian and hyporheic interfaces, where anoxic Fe(II)-enriched groundwater mixes with welloxygenated surface water (Baken et al. 2015a; Pokrovsky \& Schott 2002), before being flushed out during storm events (Kerr et al. 2008).

The elevated Al concentrations observed during storm events are also consistent with previous work in the northeast, which found greatest Al export during high flow events (Van Sickle et al. 1996). The strong correlations between dissolved Fe, $\mathrm{Al}$, and DOC have previously been attributed to the propensity for Fe-DOC and AlDOC complexes to form (Stolpe, et al. 2013; Kerr et al. 2008). The strong correlation between DOC and both dissolved and colloidal phases of Fe may just 
indicate that dissolved $\mathrm{Fe}$ is a proxy for colloidal $\mathrm{Fe}$ and that no binding is actually occurring between colloidal Fe and DOC. This appears to be a likely explanation given the strong relationship between dissolved and colloidal $\mathrm{Fe}\left(\mathrm{R}^{2}=0.806, \mathrm{r}=\right.$ 0.898 ), and previous findings, which suggest that $\mathrm{Fe}$ associated with dissolved organic matter is concentrated in the $<20 \mathrm{~nm}$ size fraction (Shiller et al. 2003).

Dissolved and colloidal Mn and dissolved P exhibited no statistically significant relationships with discharge or dissolved Si. Dissolved P concentrations were relatively low and steady throughout the study (Fig. 2), which was consistent with data collected at the same site during the 2014 sampling season and not surprising for a relatively pristine forested watershed. The slight uptick in dissolved $\mathrm{P}$ concentrations during fall storms may be a result of decreased biological uptake following the onset of autumn leaf fall, however, any effects on P export appear to be very minor. Mean dissolved Mn concentrations were lowest during periods of highest discharge (autumn storms and spring snowmelt), suggesting that dissolved $\mathrm{Mn}$ is sourced from groundwater inputs. Colloidal Mn may come from a different source than dissolved $\mathrm{Mn}$ as no discernible trends are present between colloidal $\mathrm{Mn}$ and discharge and no statistically significant relationships exist between dissolved Mn and colloidal Mn.

\section{Phosphorus transport}

Previous studies have indicated that Fe may exert a strong control on the bioavailability and transport of $\mathrm{P}$ through colloidal Fe oxyhydroxides (Baken et al. 2015b), Fe hydroxyphosphate colloids (van der Grift et al. 2014), and Fe oxyhydroxide-humic substances (Baken et al. 2016). Although no statistically significant relationships were evident between $P$ and Fe under baseflow conditions, some patterns did arise during storms. Colloidal Fe was positively correlated with dissolved $\mathrm{P}$ during summer and autumn storms $\left(\mathrm{R}^{2}=0.640\right.$ and 0.771 , respectively; Table 2). This relationship is not surprising, as laboratory studies have demonstrated that P-bearing Fe oxyhydroxides form upon the oxidation of Fe(II) in the presence of P (van der Grift et al. 2014) when anoxic groundwater mixes with well-oxygenated surface water at the riparian interface (Baken et al. 2015a). These P-bearing colloids precipitate on stream banks and are subsequently flushed into streams during high flow events. This explanation is consistent with the observed results, including the lack of a statistically significant relationship between colloidal Fe and dissolved $\mathrm{P}$ under baseflow conditions, when these P-bearing colloids are likely immobilized on stream banks and in sediment.

These results are in line with a 2014 study at this site, which found statistically significant correlations between colloidal Fe and dissolved $P$ during spring runoff and summer storms $\left(\mathrm{R}^{2}=0.904\right.$ and 0.593 , respectively) (Rosenberg \& Schroth, 2017). Interestingly, dissolved $P$ was also positively correlated with dissolved and colloidal Mn as well as dissolved Fe and DOC during autumn storms (Table 2). As these relationships were absent throughout the rest of the season, we are hesitant to conclude that these constituents are actually carriers of soluble $\mathrm{P}$ in this catchment. Due to the relative magnitude of these storm events it is more likely that 
the activation and flushing of shallow and surficial flowpaths triggered the simultaneous export of many elements that are not necessarily associated with P.

\section{Post leaf fall period}

As it has been suggested that autumn leaf may be a hot moment for DOC export from forested catchments (Meyer et al. 1998), and that DOC may be an important transport vector for dissolved Fe (Stolpe et al. 2013), the onset of autumn leaf fall was of particular interest to this study. Storms occurring after the onset of autumn leaf fall resulted in the highest DOC concentrations of the study and delivered larger fluxes of DOC than spring storms, normalized for discharge. These relatively large pulses of DOC during autumn storms are likely due to the introduction of labile organic matter to the catchment in the form of fallen leaves. 'Rain on leaves' events lead to the leaching of soluble organic compounds that are subsequently flushed into streams as DOC (Meyer et al. 1998).

The highest $\mathrm{Fe}$ and $\mathrm{Al}$ concentrations were also observed during autumn storms, with fluxes 4-5 times higher than those observed during summer storms or baseflow (Table 1). With the caveat that these autumn storms were some of the largest of the study period, it appears that the increased export of Fe, $\mathrm{Al}$, and DOC cannot be adequately explained by increased discharge alone. While metals samples were not collected during the spring of 2016, data from the 2014 spring snowmelt period indicate that DOC and colloidal Fe concentrations did not reach the same levels observed during autumn storms (Table 1). Likewise, DOC concentrations during the 2016 spring snowmelt did not reach the same levels observed during autumn storms. This suggests that storms occurring after the onset of autumn leaf result in the export of a significant portion of the annual DOC budget for this catchment. This hot transport moment contributed 23\% of total study (AprilNovember) DOC in the 2-week period from October 22 - November 5 (Fig 4).

The spike in $\mathrm{Fe}$ and $\mathrm{Al}$ concentrations during autumn storms is, in part, driven by the activation of new flowpaths, as these storms were some of the largest of the study period (Fig. 2). The heightened export of dissolved Fe and $\mathrm{Al}$ is also likely driven by increased complexation with DOC, as water is flushed over surficial flowpaths and leaf litter, and as this water percolates through soil during post leaf fall storms (Pokrovsky \& Schott 2002; Soto-Varela et al. 2015). This explanation seems plausible given the strong positive correlations between DOC and dissolved $\mathrm{Fe}\left(\mathrm{R}^{2}=0.950, \mathrm{r}=0.975\right)$ and dissolved $\mathrm{Al}\left(\mathrm{R}^{2}=0.904, \mathrm{r}=0.951\right)$ (Fig. 3$)$ and previous work, which has demonstrated the tendency for these metals to form complexes with DOC (Stolpe et al. 2013). Although our analyses cannot provide conclusive results on the extent to which DOC complexation influenced the export of $\mathrm{Fe}$ and $\mathrm{Al}$, it is clear that storm events occurring after the onset of autumn leaf fall deliver a disproportionate load of $\mathrm{Fe}, \mathrm{Al}$, and $\mathrm{DOC}$ in comparison to spring and summer storms. 


\section{Analyte projections using absorbance spectra and PLSR}

PLSR was conducted using raw absorbance spectra as well as turbiditycompensated absorbance spectra for each analyte. Calibrations using the turbiditycompensated spectra were comparable to those conducted with the raw spectra for most analytes. Calibrations using the turbidity-compensated spectra had stronger correlations between measured and predicted values for total Fe, colloidal Fe, and dissolved Si (Table 3), however more components were also required in the calibrations of colloidal Fe and dissolved Si. In general, the highly significant PLS regressions suggest that there is a quantifiable covariability between the concentrations of these parameters and the "color matrix" of water (Fig. 5). This idea has been proposed recently for dissolved Fe and Si (Birgand et al. 2016) as well as a variety of other parameters (Etheridege et al. 2014).

The calibrated PLS models were applied to a large set $(n=21,000)$ of high frequency absorbance data collected over the course of the study in order to visualize seasonal trends as well as provide insight into events that were not sampled manually. The models were able to project large fluctuations in analyte concentrations that coincided with high flow events. The PLS models provide further support for the hypothesis that the post leaf fall period is a hot moment for $\mathrm{Fe}$ and $\mathrm{Al}$ as the projected total fluxes of dissolved, colloidal, and total $\mathrm{Fe}$ as well as dissolved $\mathrm{Al}$ are greater for the 7 weeks of measurements following the onset of leaf fall than they are for the preceding 19 weeks of the study (Table 4). Coincident spikes in specific UV absorbance at $254 \mathrm{~nm}\left(\mathrm{SUVA}_{254}\right)$ provide further evidence for the projected increase in Fe export following leaf fall (Fig. 6). SUVA $_{254}$ is typically used as an indicator of DOM aromaticity; however, previous work has demonstrated the tight biogeochemical coupling between Fe and the "color" of dissolved organic matter (Maloney et al. 2005; Weyhenmeyer et al. 2014). Absorbance at $254 \mathrm{~nm}$ has been shown to increase linearly with increasing dissolved Fe concentrations (Poulin et al. 2014). It is thus reasonable to believe that the observed spike in $\mathrm{SUVA}_{254}$ following autumn leaf fall is a result of $\mathrm{Fe}$ interference due to large fluxes of dissolved and colloidal Fe from the study area (Fig. 6). This explanation makes sense in light of previous work, which suggests that leaf litter has no effect on the portion of high molecular weight DOC found in streams (Meyer et al. 1998).

While these projections must be taken with caution due to the RSE associated with each analyte (Table 3), they do provide valuable insight into seasonal fluctuations in Fe and $\mathrm{Al}$ concentrations. We did not attempt to model dissolved $\mathrm{P}$ concentrations, as any potential PLSR model would only be calibrated over the $2-\mu \mathrm{g} / \mathrm{L}$ range in concentration that was observed for dissolved P throughout the study. The strength of the PLS regressions achieved using only 22 samples should highlight how potentially powerful this technique could be to obtain information on a wide variety of parameters.

\section{Conceptual Model, Implications and Future Work}

Our findings demonstrate that loading of $\mathrm{Fe}, \mathrm{Al}$, and DOC varies seasonally, with the post leaf fall period in late autumn being a particularly hot transport moment from 
this forested catchment. We observed a large flux of DOC, representing $23 \%$ of total study export, in a 2-week period of intermittent storms following leaf fall. Our PLSR models, generated using high frequency absorbance data, also project a large fraction of total study dissolved and colloidal Fe and Al export during this period. The timing of these fluxes suggests that autumn leaf fall is an important driver in annual stream loading. Leaf fall introduces a large amount of labile DOC to forested catchments, which is subsequently flushed into streams during storm events. This DOC-enriched runoff likely leaches $\mathrm{Fe}$ and $\mathrm{Al}$ from soil, contributing a distinct biogeochemical load to streams.

As it has been suggested that autumn storms are becoming more intense and occurring later in the season (i.e. during the post-canopy leaf fall period) as a result of climate change in the northeast (Creed et al. 2015), these findings are particularly pertinent. If intense storms can be expected to occur more consistently following the leaf fall period, our results suggest that disproportionate amounts of DOC, Fe, and $\mathrm{Al}$ will be exported during this period. Indeed, elevated Fe concentrations were reported for Lake Champlain at Mississquoi Bay following intense autumn storms in 2013 (Giles et al. 2016). If autumn lake water temperatures are also warmer in the future, there will be an extended period of opportunity for algal growth. This extended growth period, coupled with the shift in timing and magnitude of autumn storms on freshly fallen leaves, could deliver a large pulse of nutrients to receiving water bodies, which could result in late season algal blooms (Creed et al. 2015).

Future work should examine the relative influence on annual loading budgets of late autumn storms compared to spring snowmelt. In this study we lacked the metals data from the spring to make this comparison, however, data from spring 2014 suggests that $\mathrm{Fe}$ is exported in similarly large fluxes for both periods (Table 1). The PLSR method described in this study shows great promise for predicting a wide variety of dissolved parameters and should be explored further with larger sample sets for calibration, and over larger ranges in concentration, in order to build more robust models. Refined application of this technique could allow for in situ, high temporal resolution measurement of many chemical parameters of interest, which would be invaluable for understanding stream dynamics during high flow events. 


\begin{tabular}{|l|c|c|c|c|c|c|c|c|}
\hline & DFe & CFe & DMn & CMn & Al & P & Si (mg/L) & $\begin{array}{c}\text { DOC } \\
(\mathrm{mg} / \mathrm{L})\end{array}$ \\
\hline $\begin{array}{l}\text { Baseflow } \\
(\mathrm{n}=12)\end{array}$ & $2.4( \pm 0.3)$ & $4.8( \pm 0.7)$ & $\begin{array}{c}2.8 \\
( \pm 0.8)\end{array}$ & $\begin{array}{c}2.1 \\
( \pm 0.3)\end{array}$ & $\begin{array}{c}10.9 \\
( \pm 0.7)\end{array}$ & $\begin{array}{c}1.2 \\
( \pm 0.1)\end{array}$ & $2.36( \pm 0.03)$ & 2.35 \\
\hline $\begin{array}{l}\text { Summer } \\
\text { storms (n =7) }\end{array}$ & $2.8( \pm 0.3)$ & $7.7( \pm 1.0)$ & $\begin{array}{c}3.4 \\
\pm 0.7)\end{array}$ & $\begin{array}{c}2.8 \\
( \pm 0.8)\end{array}$ & $\begin{array}{c}11.8 \\
( \pm 0.5)\end{array}$ & $\begin{array}{c}1.3 \\
( \pm 0.2)\end{array}$ & $2.39( \pm 0.04)$ & 4.48 \\
\hline $\begin{array}{l}\text { Post leaf fall } \\
\text { storms (n =6) }\end{array}$ & $12.8( \pm 2.9)$ & $30( \pm 3.6)$ & $\begin{array}{c}2.2 \\
( \pm 0.5)\end{array}$ & $\begin{array}{c}3.8 \\
( \pm 0.8)\end{array}$ & $\begin{array}{c}51.2 \\
( \pm 11.2)\end{array}$ & $\begin{array}{c}1.5 \\
( \pm 0.3)\end{array}$ & $1.76( \pm 0.13)$ & 5.2 \\
\hline Spring (n = 3) & 11.3 & 22.6 & 1.7 & 6.2 & - & 3.4 & - & 3.19 \\
\hline
\end{tabular}

Table 1. Mean concentrations for each chemical constituent of interest expressed in $\mu \mathrm{g} / \mathrm{L}$ (except where otherwise noted) with standard error of the mean in parentheses. Values in italics are from spring 2014. Mean DOC values are calculated from a large number $(n=21,000)$ of continuous, in-situ measurements and therefore do not correspond to the $n$ values listed.

\begin{tabular}{lcccccc|}
\hline Dissolved P & $\begin{array}{c}\text { Truly dissolved } \\
\text { Fe }\end{array}$ & $\begin{array}{c}\text { Colloidal } \\
\text { Fe }\end{array}$ & $\begin{array}{c}\text { Truly dissolved } \\
\text { Mn }\end{array}$ & $\begin{array}{c}\text { Colloidal } \\
\text { Mn }\end{array}$ & DOC & $\begin{array}{c}\text { Number of } \\
\text { samples }\end{array}$ \\
\hline Baseflow & - & - & - & - & - & $\mathrm{n}=12$ \\
Summer storms & - & 0.640 & - & - & - & $\mathrm{n}=7$ \\
Autumn storms & 0.738 & 0.771 & 0.654 & 0.654 & 0.842 & $\mathrm{n}=6$ \\
Season & 0.136 & 0.135 & - & 0.287 & 0.299 & $\mathrm{n}=25$ \\
\hline
\end{tabular}

Table 2. $R^{2}$ values for statistically significant correlations ( $p$-test; $p<0.05$ )

between dissolved P and dissolved and colloidal phases of Fe and Mn and DOC.

\begin{tabular}{|c|c|c|c|c|c|c|}
\hline & Parameters & $\begin{array}{l}\text { Number of samples } \\
\text { used for calibration }\end{array}$ & $\begin{array}{c}\text { Concentration } \\
\text { range }(\mu \mathrm{g} / \mathrm{L})\end{array}$ & $\begin{array}{l}\text { Number of } \\
\text { components } \\
\text { used in PLSR }\end{array}$ & $R^{2}$ & $\begin{array}{c}\text { 2X Residual } \\
\text { standard error } \\
(\mu \mathrm{g} / \mathrm{L})\end{array}$ \\
\hline \multirow{5}{*}{$\begin{array}{l}\text { Turbidity } \\
\text { compensated } \\
\text { spectrum }\end{array}$} & Dissolved Fe & 22 & $1-12$ & 3 & 0.89 & 1.34 \\
\hline & Colloidal Fe & 22 & $2-30$ & 5 & 0.93 & 3.15 \\
\hline & Dissolved Al & 22 & $8-80$ & 4 & 0.96 & 5.75 \\
\hline & Dissolved Si & 22 & $1375-2500$ & 6 & 0.99 & 43.10 \\
\hline & Total Fe & 22 & $4-40$ & 4 & 0.93 & 4.26 \\
\hline \multirow{5}{*}{$\begin{array}{l}\text { Raw } \\
\text { spectrum }\end{array}$} & Dissolved Fe & 22 & $1-12$ & 4 & 0.91 & 1.22 \\
\hline & Colloidal Fe & 22 & $2-30$ & 3 & 0.80 & 4.91 \\
\hline & Dissolved Al & 22 & $8-80$ & 5 & 0.97 & 5.16 \\
\hline & Dissolved Si & 22 & $1375-2500$ & 5 & 0.95 & 108.72 \\
\hline & Total Fe & 22 & $4-40$ & 4 & 0.89 & 5.20 \\
\hline
\end{tabular}

Table 3. Summary statistics for the Partial Least Squares Regression calibrations used to estimate $\mathrm{Fe}, \mathrm{Al}$, and $\mathrm{Si}$ concentrations for the 2016 sampling season at Wade Brook. 


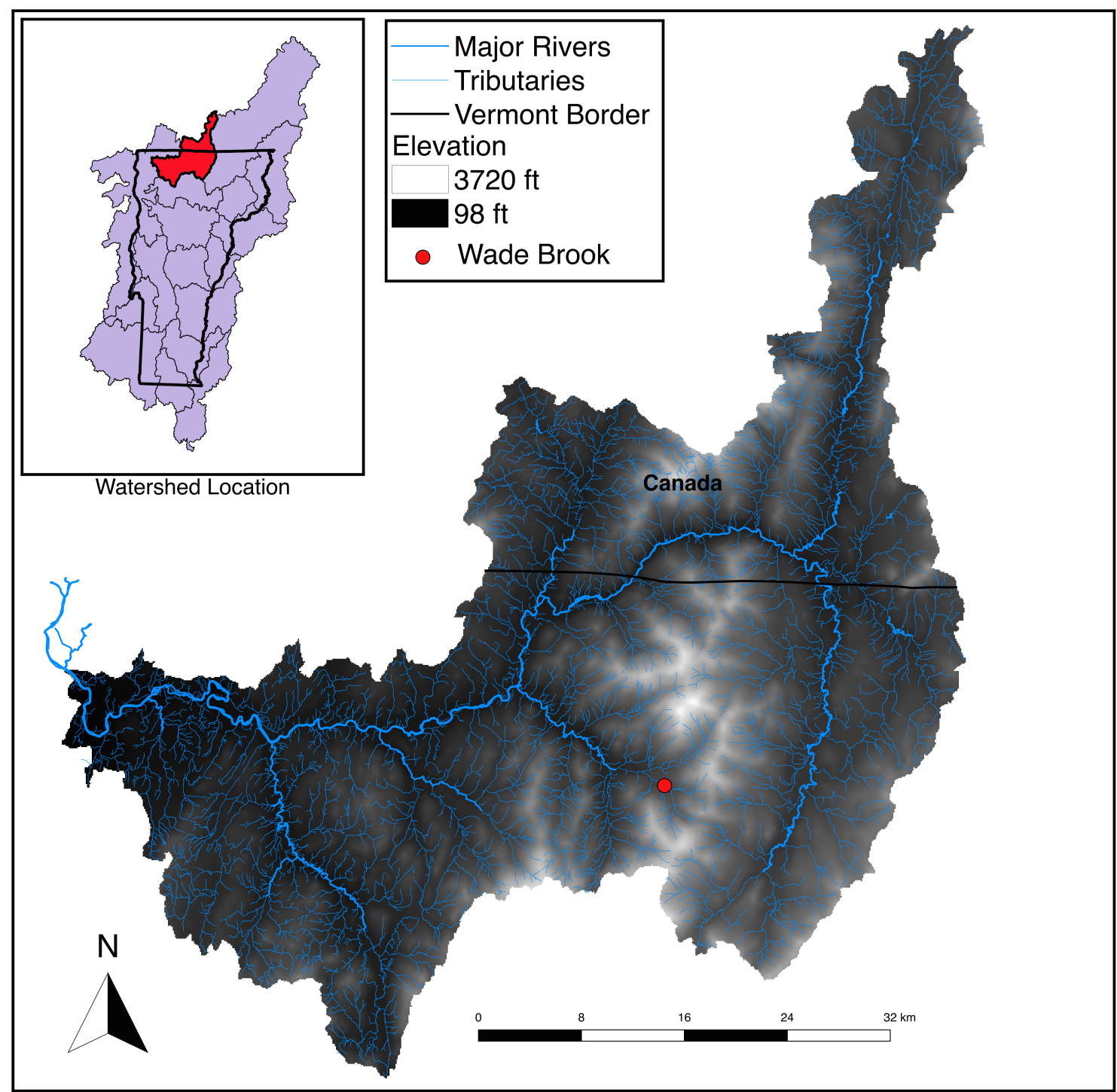

Fig. 1 Site location within the Mississquoi Basin in Vermont.

\begin{tabular}{|c|c|c|c|c|c|}
\hline & DFe & $\mathrm{CFe}$ & $\mathrm{TFe}$ & $\mathrm{Al}$ & $\mathrm{Si}$ \\
\hline $\begin{array}{l}\text { Summer } \\
\text { (Jun.1-Oct.10) }\end{array}$ & 10.11 & 21.12 & 31.74 & 64.24 & 2619 \\
\hline $\begin{array}{l}\text { Post leaf fall } \\
\text { (Oct.10-Nov.29) }\end{array}$ & 12.94 & 39.8 & 52.43 & 75.95 & 2261 \\
\hline
\end{tabular}

Table 4. Projected total flux (kg) from each PLSR model comparing the summer period to the post leaf fall period. 

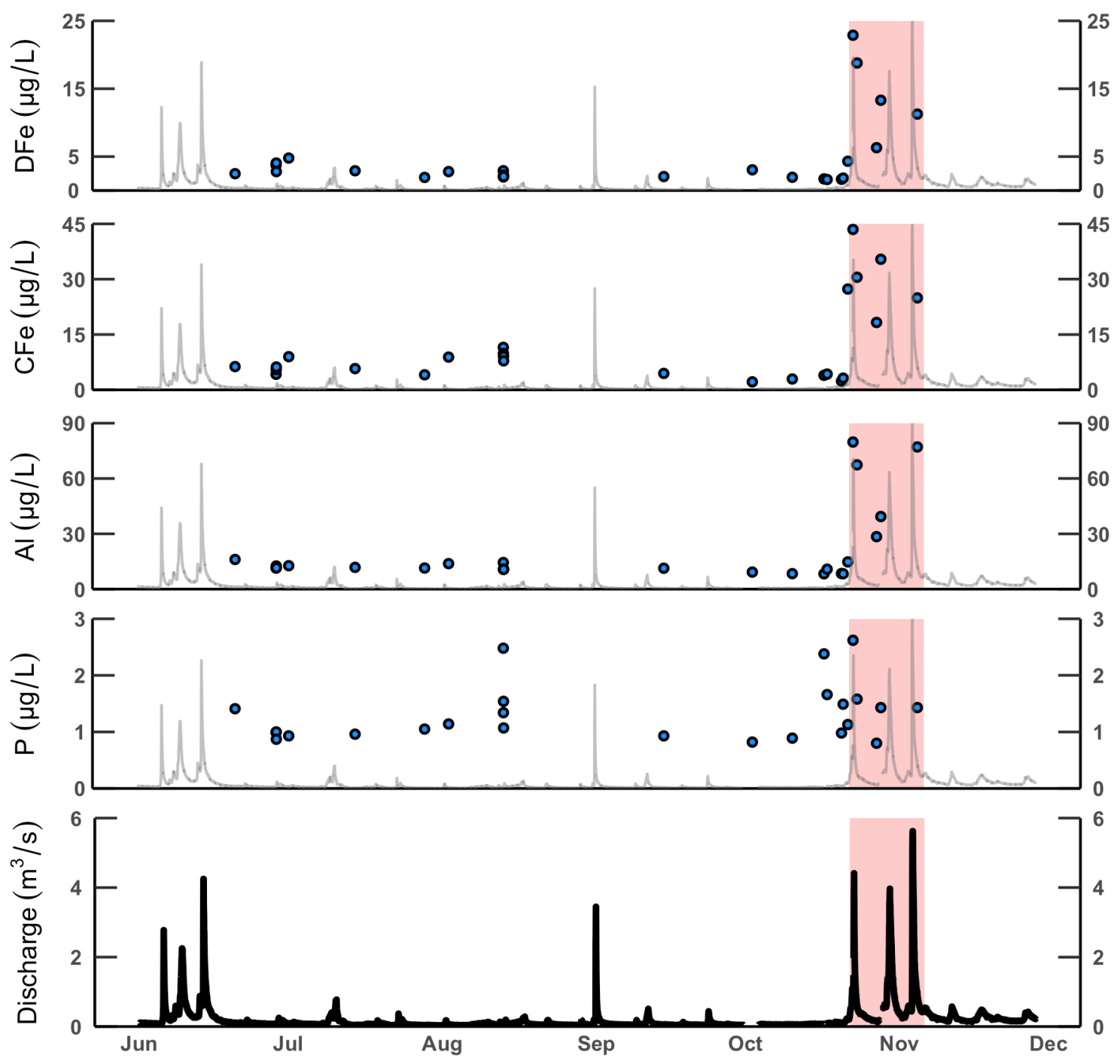

Fig. 2 Dissolved $P$ and trace metal concentrations over time. The pink window on each plot highlights the 2-week period of autumn storms. The hydrograph in the background of each plot is for reference. Refer to the bottom discharge plot for values. 

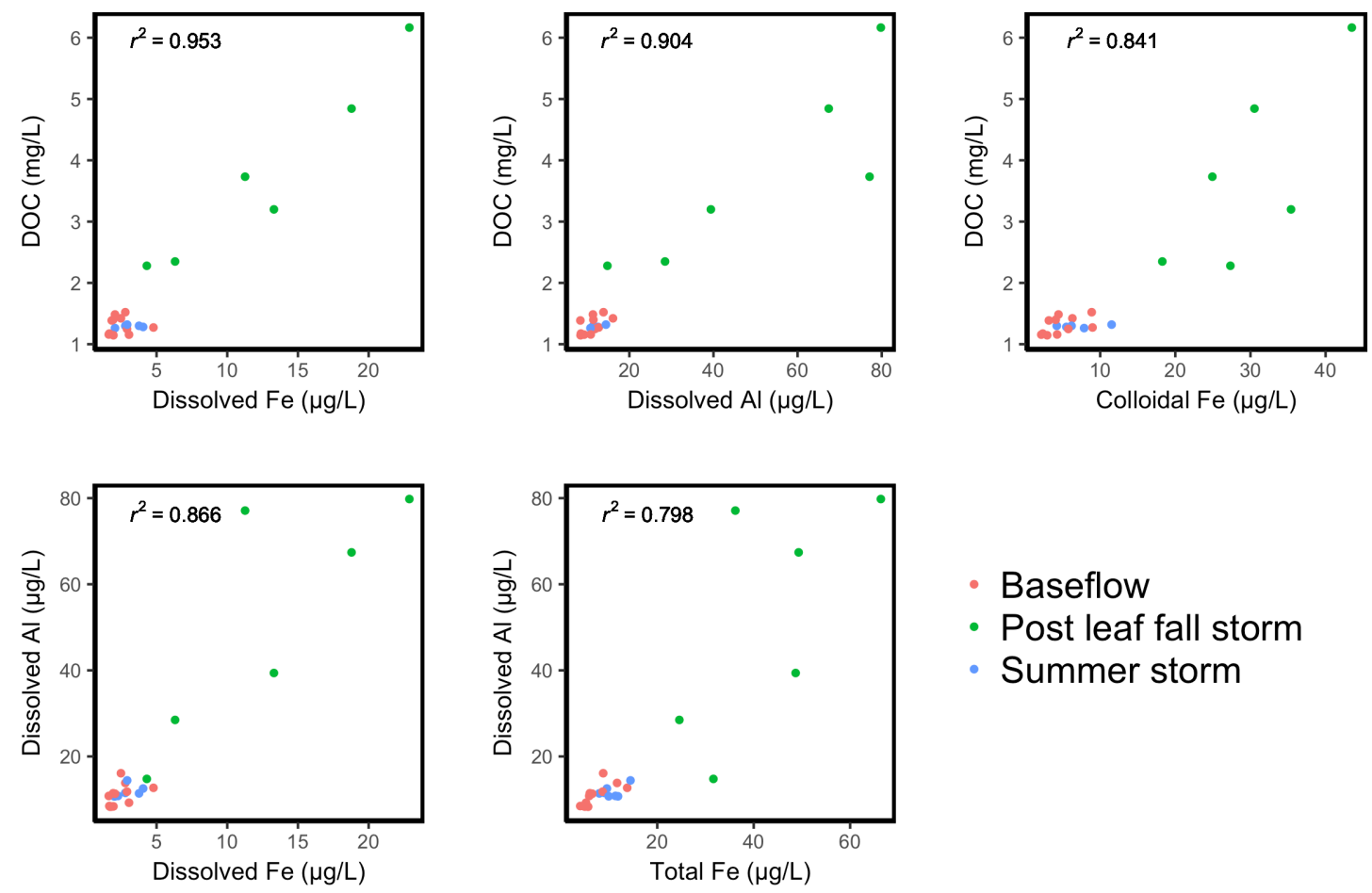

- Baseflow

- Post leaf fall storm

- Summer storm

Fig. 3 Correlation plots for statistically significant ( $p$-test; $p<0.05$ ) relationships between dissolved, colloidal, and total Fe, dissolved Al, and DOC. $\mathrm{R}^{2}$ values are noted in each plot.

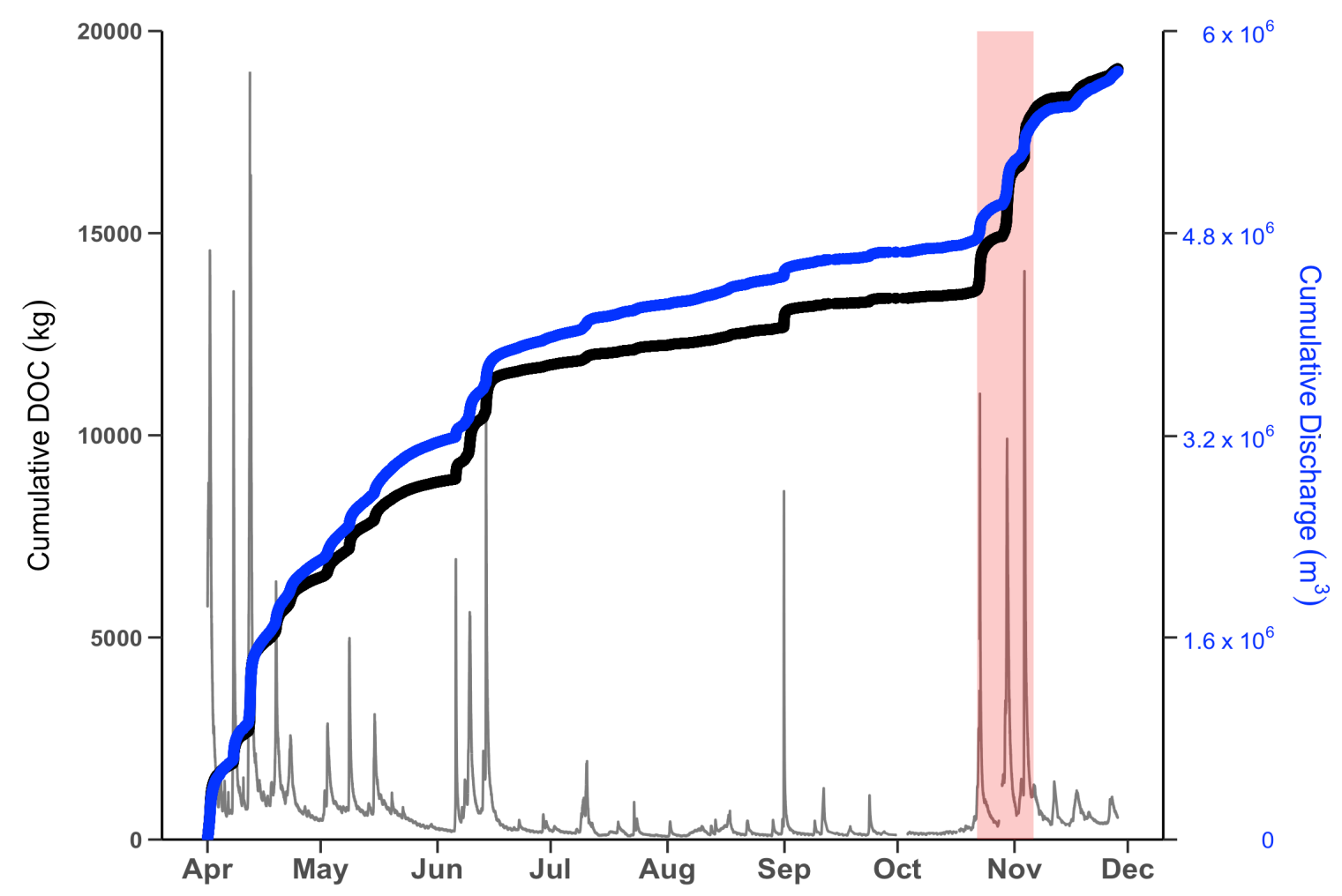

Fig. 4 Cumulative DOC and discharge over the course of the study. The hydrograph in the background is for reference and not to scale. The pink window highlights the 2-week period of autumn storms. 

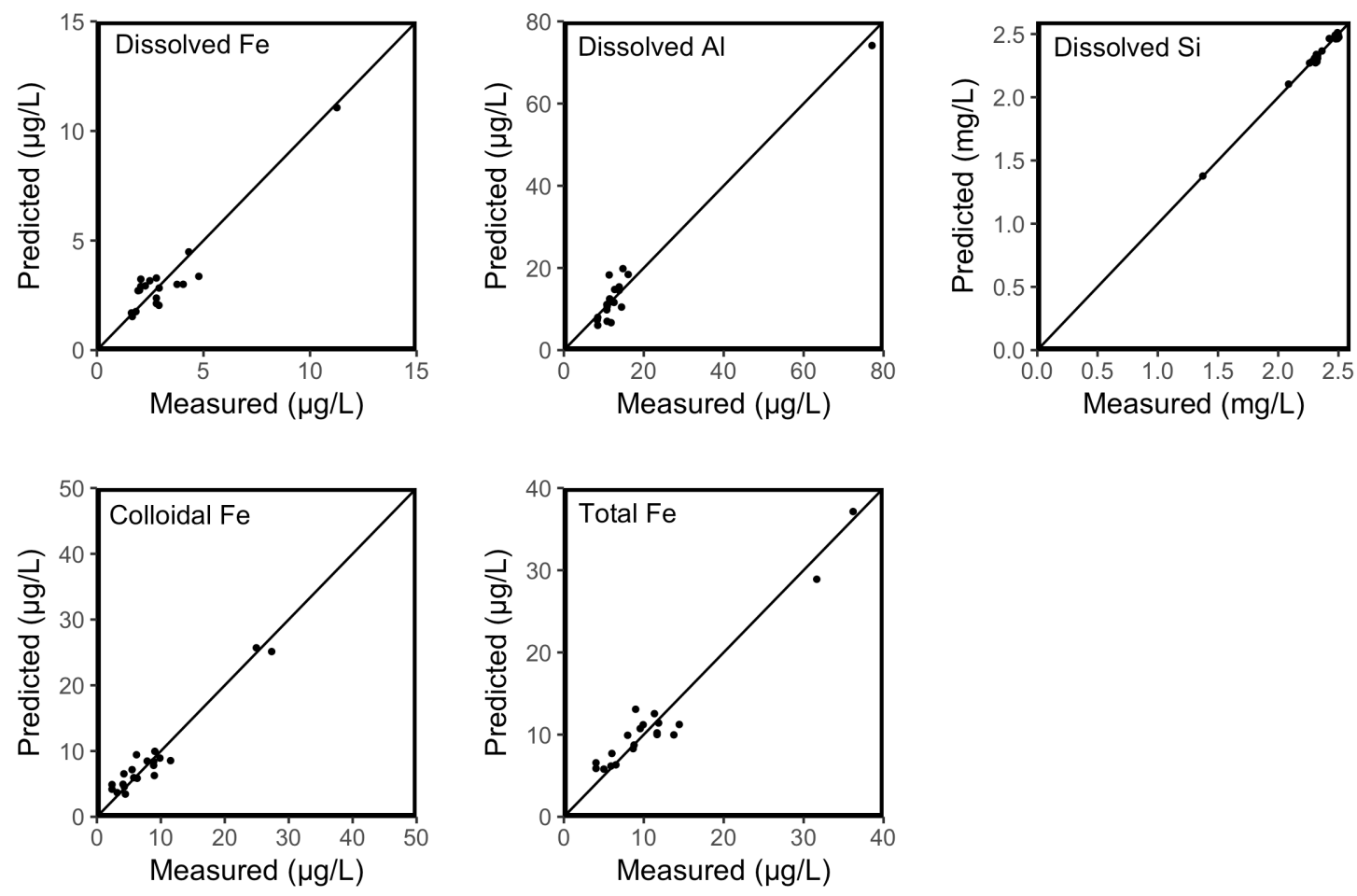

Fig. 5 Validation plots for PLSR models. Concentrations predicted from the turbidity-compensated absorbance spectra are plotted against the laboratorymeasured values.

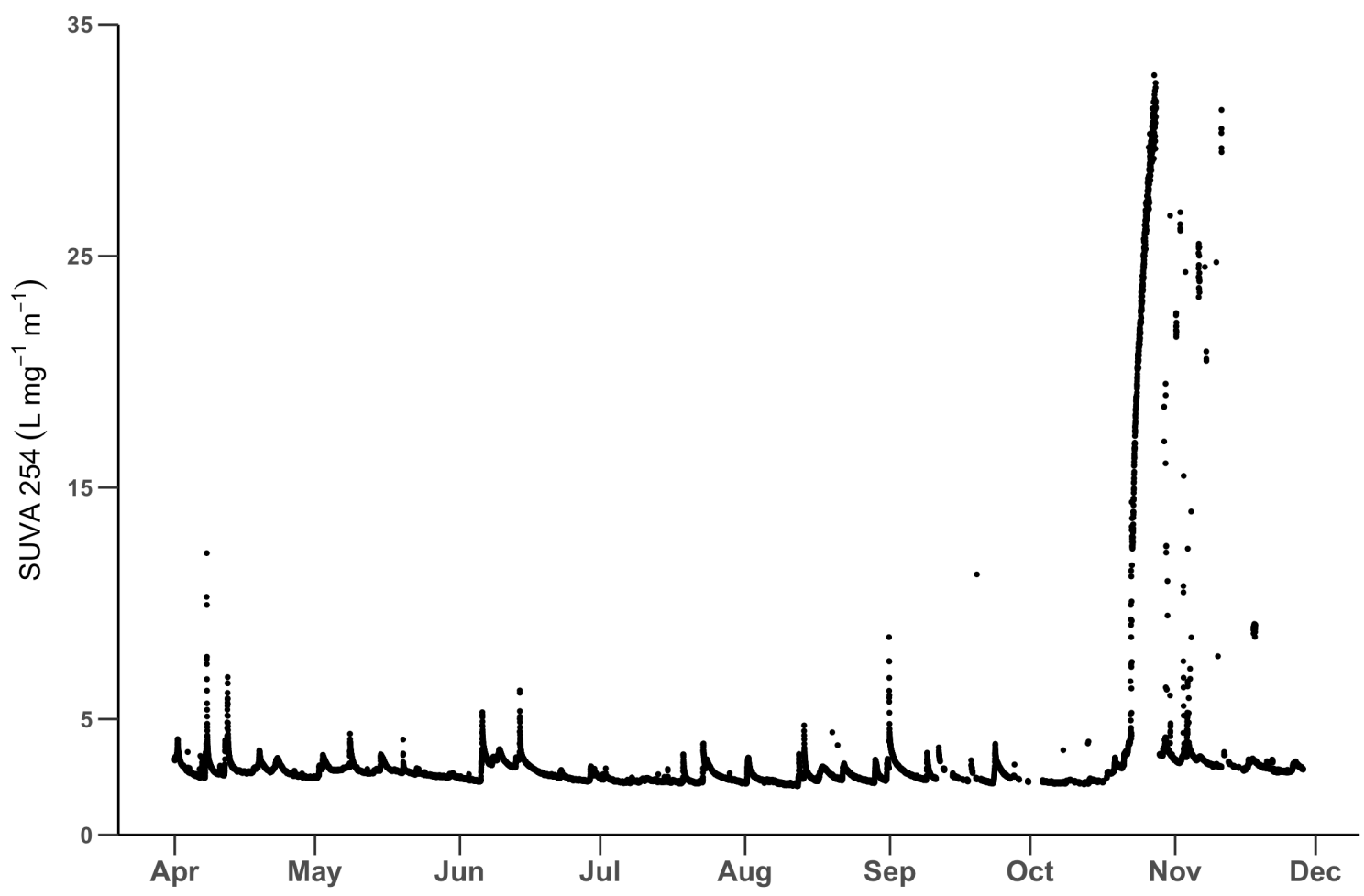

Fig. 6 Time series of specific absorbance at $254 \mathrm{~nm}$. The large spike observed in autumn is likely due to Fe interference and is not reflective of actual DOC aromaticity. 


\section{Works Cited}

Baken, S., Regelink, I. C., Comans, R. N. J., Smolders, E., \& Koopmans, G. F. (2016). Iron-rich colloids as carriers of phosphorus in streams: A field-flow fractionation study. Water Research, 99, 83-90.

doi:http://dx.doi.org/10.1016/j.watres.2016.04.060

Baken, S., Salaets, P., Desmet, N., Seuntjens, P., Vanlierde, E., \& Smolders, E. (2015a). Oxidation of Iron Causes Removal of Phosphorus and Arsenic from Streamwater in Groundwater-Fed Lowland Catchments. Environmental Science \& Technology, 49(5), 2886-2894. doi:10.1021/es505834y

Baken, S., Verbeeck, M., Verheyen, D., Diels, J., \& Smolders, E. (2015b). Phosphorus losses from agricultural land to natural waters are reduced by immobilization in iron-rich sediments of drainage ditches. Water Research, 71, 160-170.

doi:10.1016/j.watres.2015.01.008

Birgand, F., Aveni-Deforge, K., Smith, B., Maxwell, B., Horstman, M., Gerling, A. B., \& Carey, C. C. (2016). First report of a novel multiplexer pumping system coupled to a water quality probe to collect high temporal frequency in situ water chemistry measurements at multiple sites. Limnology and Oceanography: Methods, 14(12), 767-783. doi:10.1002/lom3.10122

Birgand, F., Faucheux, C., Gruau, G., Augeard, B., Moatar, F., \& Bordenave, P. (2010). Uncertainties in Assessing Annual Nitrate Loads and Concentration Indicators: Part 1. Impact of Sampling Frequency and Load Estimation Algorithms. 53(2). doi:10.13031/2013.29584

Creed, I. F., Hwang, T., Lutz, B., \& Way, D. (2015). Climate warming causes intensification of the hydrological cycle, resulting in changes to the vernal and autumnal windows in a northern temperate forest. Hydrological Processes, 29(16), 3519-3534. doi:10.1002/hyp.10450

E.P.A., U. S. (2015). Vermont Lake Champlain Phosphorus TMDL Phase 1 Implementation Plan. 16.

Etheridge, J. R., Birgand, F., Osborne, J. A., Osburn, C. L., Burchell, M. R., \& Irving, J. (2014). Using in situ ultraviolet-visual spectroscopy to measure nitrogen, carbon, phosphorus, and suspended solids concentrations at a high frequency in a brackish tidal marsh. Limnology and Oceanography-Methods, 12, 10-22. doi:10.4319/lom.2014.12.10

Giles, C. D., Isles, P. D. F., Manley, T., Xu, Y., Druschel, G. K., \& Schroth, A. W. (2016). The mobility of phosphorus, iron, and manganese through the sediment-water continuum of a shallow eutrophic freshwater lake under stratified and mixed watercolumn conditions. Biogeochemistry, 127(1), 15-34. doi:10.1007/s10533-0150144-x 
Inamdar, S., Singh, S., Dutta, S., Levia, D., Mitchell, M., Scott, D., .. McHale, P. (2011). Fluorescence characteristics and sources of dissolved organic matter for stream water during storm events in a forested mid-Atlantic watershed. Journal of Geophysical Research: Biogeosciences, 116(G3), n/a-n/a. doi:10.1029/2011JG001735

Kerr, S. C., Shafer, M. M., Overdier, J., \& Armstrong, D. E. (2008). Hydrologic and biogeochemical controls on trace element export from northern Wisconsin wetlands. Biogeochemistry, 89(3), 273-294. doi:10.1007/s10533-008-9219-2

Maloney, K. O., Morris, D. P., Moses, C. O., \& Osburn, C. L. (2005). The role of iron and dissolved organic carbon in the absorption of ultraviolet radiation in humic lake water. Biogeochemistry, 75(3), 393-407. doi:10.1007/s10533-005-1675-3

Meyer, L. J., Wallace, B. J., \& Eggert, L. S. Leaf Litter as a Source of Dissolved Organic Carbon in Streams. Ecosystems, 1(3), 240-249. doi:10.1007/s100219900019

Molot, L. A., Watson, S. B., Creed, I. F., Trick, C. G., McCabe, S. K., Verschoor, M. J., ... Schiff, S. L. (2014). A novel model for cyanobacteria bloom formation: the critical role of anoxia and ferrous iron. Freshwater Biology, 59(6), 1323-1340. doi:10.1111/fwb.12334

Pokrovsky, O. S., \& Schott, J. (2002). Iron colloids/organic matter associated transport of major and trace elements in small boreal rivers and their estuaries (NW Russia). Chemical Geology, 190(1-4), 141-179. doi:http://dx.doi.org/10.1016/S0009-2541(02)00115-8

Poulin, B. A., Ryan, J. N., \& Aiken, G. R. (2014). Effects of Iron on Optical Properties of Dissolved Organic Matter. Environmental Science \& Technology, 48(17), 1009810106. doi:10.1021/es502670r

Rabajczyk, A., Namie, \& nik, J. (2014). Speciation of Iron in the Aquatic Environment. Water Environment Research, 86(8), 741-758.

doi:10.2175/106143014X13975035525906

Raymond, P. A., \& Saiers, J. E. (2010). Event controlled DOC export from forested watersheds. Biogeochemistry, 100(1-3), 197-209. doi:10.1007/s10533-010-9416-7

Rosenberg, B. D., \& Schroth, A. W. (2017). Coupling of reactive riverine phosphorus and iron species during hot transport moments: impacts of land cover and seasonality. Biogeochemistry, 1-20. doi:10.1007/s10533-016-0290-9

Sebestyen, S. D., Boyer, E. W., \& Shanley, J. B. (2009). Responses of stream nitrate and DOC loadings to hydrological forcing and climate change in an upland forest of the northeastern United States. Journal of Geophysical Research: Biogeosciences, 114(G2), n/a-n/a. doi:10.1029/2008JG000778 
Sebestyen, S. D., Boyer, E. W., Shanley, J. B., Kendall, C., Doctor, D. H., Aiken, G. R., \& Ohte, N. (2008). Sources, transformations, and hydrological processes that control stream nitrate and dissolved organic matter concentrations during snowmelt in an upland forest. Water Resources Research, 44(12), n/a-n/a.

doi:10.1029/2008WR006983

Shiller, A. M. (2003). Syringe Filtration Methods for Examining Dissolved and Colloidal Trace Element Distributions in Remote Field Locations. Environmental Science \& Technology, 37(17), 3953-3957. doi:10.1021/es0341182

Sorichetti, R. J., Creed, I. F., \& Trick, C. G. (2014). The influence of iron, siderophores and refractory DOM on cyanobacterial biomass in oligotrophic lakes. Freshwater Biology, 59(7), 1423-1436. doi:10.1111/fwb.12355

Soto-Varela, F., Rodríguez-Blanco, M. L., Taboada-Castro, M. M., \& Taboada-Castro, M. T. (2015). Metals discharged during different flow conditions from a mixed agricultural-forest catchment (NW Spain). Hydrological Processes, 29(6), 16441655. doi:10.1002/hyp.10282

Stolpe, B., Guo, L., Shiller, A. M., \& Aiken, G. R. (2013). Abundance, size distributions and trace-element binding of organic and iron-rich nanocolloids in Alaskan rivers, as revealed by field-flow fractionation and ICP-MS. Geochimica et Cosmochimica Acta, 105, 221-239. doi:http://dx.doi.org/10.1016/j.gca.2012.11.018

van der Grift, B., Rozemeijer, J. C., Griffioen, J., \& van der Velde, Y. (2014). Iron oxidation kinetics and phosphate immobilization along the flow-path from groundwater into surface water. Hydrol. Earth Syst. Sci., 18(11), 4687-4702. doi:10.5194/hess-18-4687-2014

Van Sickle, J., Baker, J. P., Simonin, H. A., Baldigo, B. P., Kretser, W. A., \& Sharpe, W. E. (1996). Episodic Acidification of Small Streams in the Northeastern United States: Fish Mortality in Field Bioassays. Ecological Applications, 6(2), 408-421. doi: $10.2307 / 2269379$

Vidon, P., Allan, C., Burns, D., Duval, T. P., Gurwick, N., Inamdar, S., ... Sebestyen, S. (2010). Hot Spots and Hot Moments in Riparian Zones: Potential for Improved Water Quality Management1. JAWRA Journal of the American Water Resources Association, 46(2), 278-298. doi:10.1111/j.1752-1688.2010.00420.x

Weyhenmeyer, G. A., Prairie, Y. T., \& Tranvik, L. J. (2014). Browning of Boreal Freshwaters Coupled to Carbon-Iron Interactions along the Aquatic Continuum. PLoS ONE, 9(2), e88104. doi:10.1371/journal.pone.0088104

Williamson, C. E., Overholt, E. P., Pilla, R. M., Leach, T. H., Brentrup, J. A., Knoll, L. B., Moeller, R. E. (2015). Ecological consequences of long-term browning in lakes. Scientific Reports, 5, 18666. doi:10.1038/srep18666 